też niekompletność kontraktów. Firma widziana jest jako organizacja, której wewnętrzna struktura powinna być taka, aby w jak największym stopniu ograniczać niesprawności rynków w alokacji dostẹpnych zasobów produkcyjnych.

Teorie rozumiejące produkcję jako proces tworzenia zasobów, kreowania nowych opcji produkcyjnych i ich wykorzystania nie posługują się pojęciem równowagi. Akcentują proces produkcyjny rozciągnięty w rzeczywistym czasie. Stąd istotny staje siẹ proces uczenia siẹ, zdobywania wiedzy, która w przeciwieństwie do informacji może być nieprzekazywalna. Taka wiedza w formie kompetencji, rutyn czy umiejętności może być podstawą konkurencyjności firm. Struktura firmy oraz jej relacje z otoczeniem powinny mieć na celu odpowiednią koordynację procesu uczenia się, zdobywania wiedzy i jej wykorzystania w wytwarzaniu dóbr i usług. Do tego nurtu zaliczają się teorie kompetencyjne i ewolucyjna.

\title{
Witold JAKÓBIK
}

\section{Drogi do rozwiniętej gospodarki rynkowej}

W literaturze dominuje pogląd, ze wspótczesna gospodarka kapitalistyczna nie jest monolitem, lecz tworzy kilka podstawowych modeli. Wspólne dla nich sq wszakże pewne cechy, które można określić jako atrybuty rozwiniętej gospodarki rynkowej: w petni uksztaltowanej pod względem instytucjonalnym i charakteryzujacej się wysokim poziomem PKB per capita. To wlaśnie te atrybuty sq drogowskazem w procesach zmiany systemowej, jaka odbywa się w Europie Srodkowo-Wschodniej.

W artykule podejmuje próbę: a) opracowania listy wspomnianych atrybutów, tworzacych układ docelowy dla krajów postkomunistycznych; b) nakreślenia dwóch podstawowych "dróg dojścia" do uktadu docelowego, po kıórych kroczq liderzy lub outsiderzy transformacji; c) scharakteryzowania czynników determinujących "drogi dojścia".

\section{Atrybuty gospodarki rozwiniętej - układ docelowy}

Mimo iż współcześnie istnieją rozbudowane więzi ekonomiczne między krajami Zachodu, powodujące pewną unifikację rozwiązań instytucjonalnych, to jednak wzorzec kapitalistyczny nie jest wewnętrznie spójny. Przeciwnie, wielu znanych badaczy (Havrylyshyn, 1980; Thurow, 1992; Albert, 1994; Koź-

Autor jest pracownikiem naukowym Instytutu Nauk Politycznych PAN. 
miński, 1997; Kowalik, 2000) wyróżnia kilka modeli gospodarki kapitalistycznej, stosując przy tym różne kryteria ich podziału (tabl. 1). Nie rozwijając nadmiernie tego tematu, warto wszakże wskazać na kilka nowych kwestii.

Pierwsza dotyczy oceny atrakcyjności kapitalizmu azjatyckiego (głównie japońskiego) na tle pozostałych modeli kapitalizmu, w związku z kryzysem ekonomicznym, który w latach 1997-1998 wstrząsnął Azją Południowo-Wschodnią. Kwestia ta wydaje się tym bardziej istotna, że kapitalizm azjatycki przez wiele lat cechował się najwyższą w świecie dynamiką rozwoju: roczne tempo wzrostu PKB wynosiło 5-10\%. Tymczasem np. w Japonii, w latach 1990-95, średnia dla tego okresu stopa wzrostu PKB wynosiła około 1\%, sygnalizując stagnację, zaś w 1998 r. stopa przyrostu PKB miala wartość ujemną: - 2,8\%.

Tabl. 1

Wspólczesne modele gospodarki kapitalistycznej

\begin{tabular}{|c|c|c|c|}
\hline \multirow{2}{*}{$\begin{array}{l}\text { Modele } \\
\text { gospodarki }\end{array}$} & \multicolumn{3}{|c|}{ Kryteria wyrózinienia } \\
\hline & wartości spoleczne & stosunki pracy & rola rządu \\
\hline $\begin{array}{l}\text { Anglo-amerykański } \\
\text { kapitalizm konkurencyjny }\end{array}$ & skrajny indywidualizm & $\begin{array}{l}\text { konfrontacja na rynku } \\
\text { pracy }\end{array}$ & $\begin{array}{l}\text { ochrona i kontrola } \\
\text { instytucji rynkowreh }\end{array}$ \\
\hline $\begin{array}{l}\text { Europejska spolectna" } \\
\text { gospodarka rynkowa }\end{array}$ & solidarność spoleczna & $\begin{array}{l}\text { kombinacja rynku } \\
\text { pracy i negocjacji } \\
\text { nierynkowych }\end{array}$ & $\begin{array}{l}\text { aktywna polityka } \\
\text { fiskalna: wysokie } \\
\text { podatki i wydatki } \\
\text { publiczne }\end{array}$ \\
\hline Nowa „trzecia droga" & $\begin{array}{l}\text { wlączenie do życia } \\
\text { spolecznego ,inclusion”) } \\
\text { ludzi zmarginalizowanych }\end{array}$ & $\begin{array}{l}\text { „welfare-to-work"; } \\
\text { publiczna pomoc } \\
\text { stwarzająca rúwne } \\
\text { szanse odzyskania pracy }\end{array}$ & $\begin{array}{l}\text { wykorzystanie } \\
\text { dynamiki rynku } \\
\text { w interesie } \\
\text { publicznym }\end{array}$ \\
\hline $\begin{array}{l}\text { Nordycki kapitalizm } \\
\text { gospodarki negocjacyjnej }\end{array}$ & $\begin{array}{l}\text { spoleczny konsens } \\
\text { na wszystkich poziomach } \\
\text { gospodarki }\end{array}$ & $\begin{array}{l}\text { negocjacje placowo- } \\
\text {-zatrudnieniowe glównie } \\
\text { na poziomie regionu } \\
\text { ilub branžy }\end{array}$ & $\begin{array}{l}\text { kontrola nad } \\
\text { podatkami osobistymi } \\
\text { i indywidualnym } \\
\text { dobrobytem }\end{array}$ \\
\hline $\begin{array}{l}\text { Kapitalizm azjatycki } \\
\text { (glównie japoński) }\end{array}$ & $\begin{array}{l}\text { interes ekonomiczny } \\
\text { grupy spolecznej, firmy, } \\
\text { kraju }\end{array}$ & $\begin{array}{l}\text { partycypacja } \\
\text { pracownicza; kontrakt } \\
\text { o karierę w firmie }\end{array}$ & $\begin{array}{l}\text { kompleksowa polityka } \\
\text { wzrostu i rozwoju } \\
\text { ekonomicznego }\end{array}$ \\
\hline
\end{tabular}

Źródło: opracowanie własne

Wśród przyczyn kryzysu lat 90., na plan pierwszy wysuwane są następujące (Hussain i Wihlborg, 1999): a) błẹdy polityki gospodarczej, polegające m.in. na nadmiernym protekcjonizmie i przeregulowaniu gospodarki, b) instytucjonalne wady modelu azjatyckiego, przede wszystkim w dziedzinie bankowości i rynków finansowych, c) krach na międzynarodowym rynku kapitału spekulacyjnego. Ten ostatni czynnik wskazuje na to, że przyczyny owego kryzysu nie miały wylącznie charakteru wewnẹtrznego wobec modelu azjatyckiego, który 
- nawiasem mówiąc - w coraz większym stopniu podlega wplywom ze strony świata zewnętrznego (m.in. USA).

Objawy rozszerzającego się kryzysu finansowego skłoniły rządy wielu krajów Azji Poludniowo-Wschodniej do skorzystania z pomocy finansowej i programów naprawczych, które przeforsował Bank Światowy oraz Międzynarodowy Fundusz Walutowy. W rezultacie nastąpiło m.in. większe otwarcie na konkurencyjny import, dopuszczono miẹdzynarodowy kapitał finansowy do bankowości i (selektywnie) do ubezpieczeń, rozwaźana jest również moźliwość utworzenia Unii Azjatyckiej. Tendencje integracyjne, obejmujące kraje ASEAN oraz Japonię, Koreę Południową, a nawet Chiny, oznaczają perspektywę powołania do życia największego współcześnie bloku ekonomicznego. Można przypuszczać, że podjęcie tych działań przyczyniło się do zażegnania objawów kryzysu już pod koniec 1998 r., zaś w następnym roku odnotowano oznaki boomu (czego spektakularnym przejawem był wzrost PKB o 13\% w Korei Południowej).

Uwzględniając wszystkie wymienione fakty i tendencje można sformułować - być może - dyskusyjny wniosek: kryzys ostatniej dekady nie tyle obniżył atrakcyjność modelu azjatyckiego, ile wyeksponował jego adaptacyjność i zdolność do „samodoskonalenia się”. Wniosek ten wydaje się potwierdzać prognoza Azjatyckiego Banku Rozwoju, w świetle której w bieżącym roku w Azji PKB bẹdzie o ponad 6\% wyższy od ubiegłorocznego (The Economist, April 17, 1999).

Kolejna kwestia, jaka ostatnio pojawila siẹ w dyskusji wokół modeli kapitalizmu, dotyczy powstawania tzw. nowej „trzeciej drogi”. Źródeł tego modelu należy poszukiwać w fakcie absolutnej dominacji partii socjaldemokratycznych w Europie, zaś wiodącą ideową rolę spełniają tu centrolewicowe koncepcje T. Blaira i G. Schroedera (Kowalik, 2000). Dotychczasowe doświadczenia wszakże wskazują na Wielką Brytanię jako najbardziej zaawansowany przypadek „nowej" gospodarki.

Pomijając formułowane przez T. Blaira deklaracje polityczne (zmieniają się one w czasie i są, do pewnego stopnia, eklektyczne), warto podkreślić jego ekonomiczne dokonania. Likwidując lub ograniczając regulację państwa tam, gdzie krępuje ona efektywność rynku, rząd T. Blaira potrafi wykorzystać owoce wzrostu dla realizacji programu społecznego, który obejmuje: gwarantowaną placę minimalną, dotowane kredyty dla biednych rodzin, podwyższone nakłady na żłobki i przedszkola, ustawiczne kształcenie młodzieży itp. Państwo pełni jednak nie tyle klasyczne funkcje opiekuńcze, ile rolę kreatora równych szans dla wszystkich. Szczególnym tego przejawem jest reguła „welfare-to-work", oznaczająca publiczną pomoc, która stwarza szansẹ odzyskania zatrudnienia.

Wdrażanie nowego modelu kapitalizmu znalazło intelektualne wsparcie w dorobku wybitnego brytyjskiego socjologa A. Giddensa, którego koncepcja nowej „trzeciej drogi” okazała się daleko bardziej spójna i kompleksowa niż polityczne zamierzenia i dokonania rządu T. Blaira (Giddens, 1999). Koncen- 
trując analizę wokól ekonomicznych wątków, należy wskazać na dwie fundamentalne dla tej koncepcji zasady: a) wzajemnego wzmacniania się sektora rynkowego i sektora publicznego oraz dążenia do równowagi we wszystkich sferach życia społeczno-ekonomicznego, b) włączania do społeczeństwa ludzi zmarginalizowanych (co nie jest równoznaczne z lewicową regułą państwa opiekuńczego, ani z liberalną zasadą równych szans). Jak latwo zauważyć, zwłaszcza ostatnia kwestia różni nieco poglądy A. Giddensa od praktycznych dokonań, które wydają siẹ odzwierciedlać zbitkę idei liberalnych oraz nowej socjaldemokracji. Czas zapewne pokaże, czy dokonania rządu okażą się bardziej jednoznaczne.

Poszukiwanie odpowiedzi na pytanie, który z modeli gospodarki kapitalistycznej może okazać siẹ optymalny z punktu widzenia transformacyjnych potrzeb danego kraju postkomunistycznego, byłoby chybione. Przemawia za tym nie tylko kulturowa czy, po czéści, cywilizacyjna odmienność spoleczeństw i gospodarek Wschodu oraz Zachodu, ale również dyskusyjność „konstruktywistycznego" podejścia do transformacji systemowej. Ten hayekowski, pejoratywnie zabarwiony „konstruktywizm” oznacza, że pewien ośrodek decyzyjny może konstruować systemy i instytucje spoleczne według niemal dowolnie przyjętego planu (Godlów-Legiẹdź, 1992). Przyświeca temu często przeświadczenie o moźliwości wykonania rewolucyjnego skoku do nowego systemu społeczno-ekonomicznego, co miałoby minimalizować ogólnospołeczne koszty przechodzenia do nawego ładu. Najgłębszą krytykẹ takiego podejścia do transformacji społecznej wydaje się zawierać teoremat ewolucji kulturowej, sformulowany właśnie przez Friedricha von Hayeka.

Analiza modeli gospodarki kapitalistycznej wskazuje, że mają one również wspólne cechy, które można nazwać atrybutami wspólczesnej gospodarki rozwiniętej. Atrybuty te, jak się wydaje, powinny stanowić układ docelowy dla krajów postkomunistycznych, wytyczający zasadniczy schemat gospodarki. Natomiast ów schemat bylby wypełniany konkretnymi rozwiązaniami w sposób ewolucyjny, pod wplywem zmieniających się uwarunkowań - wewnętrznych i zewnętrznych.

Za przyjęciem atrybutów gospodarki rozwiniẹtej jako układu docelowego przemawiają czynniki zarówno obiektywne, jak i subiektywne. Te pierwsze, to historycznie potwierdzona wysoka efektywność alokacji zasobów, dokonywanej przez mechanizm rynkowy w warunkach kontrolno-modyfikującej roli państwa. Najlepszym dowodem na znaczną efektywność tego typu alokacji jest imponująca wielkość przeciętnego dobrobytu indywidualnego na Zachodzie, mierzona za pomocą wartości PKB per capita (obecnie wartość ta jest od dwóch do ośmiu razy wię̧ksza niż w krajach przechodzących transformację systemową).

Do czynników subiektywnych można z kolei zaliczyć zglaszane explicite lub implicite deklaracje elit reformatorskich w tych krajach, dotyczące zapewnienia wolności politycznej i ekonomicznej. Wolność polityczna może przy tym być traktowana w różny sposób. Po pierwsze, może stanowić wartość sa- 
mą w sobie, będącą przez stulecia przedmiotem dążeń człowieka. Po drugie, wolność polityczna determinuje wolność ekonomiczną, gdyź na długą metę instytucje rynkowe i rozwój gospodarczy nie mogą istnieć bez demokracji. Argument, że rynek może sprawnie funkcjonować, a wzrost jest zapewniony niezależnie od ładu politycznego, sprawdza się tylko do pewnego momentu i jedynie w przypadku krajów zacofanych. Ten szczególny splot wolności politycznej i ekonomicznej jest faktem obiektywnym i dlatego został zaakceptowany przez elity polityczne w Europie Wschodniej.

Atrybuty, czyli cechy wspólne dla wszystkich wyróżnionych modeli gospodarki rozwiniętej, mogą być przypisane do: a) sfery instytucjonalnej, która obejmuje reguły gry w gospodarce narodowej, kształtujące rynek oraz rolę państwa; b) sfery polityki ekonomicznej rządu. Analizując sferę instytucjonalną moźna wyróżnić następujące atrybuty mechanizmu rynkowego:

- koordynacja decyzji (zamierzeń) ekonomicznych sprzedawców i nabywców ma charakter poziomy i bezpośredni;

- w aspekcie przedmiotowym transakcje rynkowe obejmują dobra rzeczowe, pieniądz plynny oraz aktywa finansowe, chociaż zwlaszcza w ostatnim przypadku intensywność transakcji bywa róźna;

- w aspekcie podmiotowym istnieje różnorodność przedsiębiorstw tworzących produkt narodowy, zaś wybór profilu działalności i rynku cząstkowego jest dziełem samych przedsiębiorstw, z pominięciem jakichkolwiek ogniw zewnętrznych;

- przeważającym (choć nie jedynym) typem informacji ekonomicznej są ceny zasobów i produktów;

- prawne ramy rynku są zdominowane przez tzw. property rights paradigm (Pejovich, 1990), czyli przez prawa własności wyłącznej i kompletnej, aczkolwiek są one stopniowalne w czasie i przestrzeni.

W sferze instytucjonalnej, atrybuty dotyczące roli państwa obejmują:

- tworzenie instytucjonalno-prawnych podstaw działania rynku, czego przykładem może być deregulacja, liberalizacja obrotów z zagranicą lub prywatyzacja (bądź przeciwnie - wzrost regulacji państwa, nacjonalizacja pewnych sektorów itp.);

- projektowanie ogólnych reguł polityki ekonomicznej rządu, ilustracją jest tu wybór selektywności oddziaływania rządu na strukturę przemyslową kraju;

- korygowanie niekorzystnych następstw działania rynku (efektów zewnętrznych, których przykładem są choroby cywilizacyjne) przy użyciu niecenowej informacji ekonomicznej: zakazów, nakazów, zaleceń itp.;

- ustalanie w procesie politycznym zakresu redystrybucji dochodu narodowego (m.in. kwestia ulg podatkowych, zasiłków, kredytów publicznych).

W odniesieniu do sfery polityki ekonomicznej rządu znacznie trudniej jest sformułować atrybuty, które byłyby wspólne dla wyróżnionych modeli gospodarki kapitalistycznej. Powódem jest fakt, iż cele tej polityki oraz instrumenty ich realizacji są stosunkowo zróżnicowane, ponadto zmieniają się z upływem 
czasu. Tym niemniej można wskazać na politykę stabilizacji gospodarczej jako ten typ polityki, który relatywnie często bywa stosowany przez rząd w różnych krajach (zwłaszcza w porównaniu z politykami mikroekonomicznymi, jak np. polityką przemysłową czy regionalną). Polityka stabilizacyjna oznacza przywracanie gospodarki do stanu równowagi wewnętrznej i zewnętrznej; chodzi tu o eliminowanie utrzymującej się w kraju presji inflacyjnej i deficytu w bilansie platniczym, równocześnie zaś - o zapewnienie wzrostu gospodarczego jako trwałej podstawy stabilizacji (Dornbusch, 1996). Specyficznym zbiorem działań stabilizacyjnych są programy dostosowawcze MFW, mające formę: a) ortodoksyjną, opartą na eliminacji deficytu budżetowego, czemu towarzyszy operowanie podażą pieniądza i/lub kursem walutowym; b) heterodoksyjną, która - oprócz wymienionych już działań - obejmuje politykę dochodów (kontrola cen i/lub plac).

\section{„Drogi dojścia”: liderzy transformacji}

Teoretycznie rzecz biorąc, istnieją co najmniej dwa alternatywne kryteria podziału krajów postkomunistycznych, przechodzących obecnie transformację: a) sposób dokonywania zmiany - szokowy lub stopniowy; b) stan koniunktury gospodarczej - recesja lub ożywienie charakteryzujące się przyrostem PKB o strukturze, która jest zdominowana przez finalne dobra konsumpcyjne o wysokiej uźyteczności oraz przez finalne dobra inwestycyjne będące nośnikiem postępu technicznego (w dalszej analizie ten rodzaj PKB otrzyma nazwẹ „nowoczesny").

Przydatność tych kryteriów dla analizy nie jest wszakże jednakowa. O ile bowiem kryterium a) może być zastosowane tylko w odniesieniu do stabilizacji makroekonomicznej (Murrell, 1990), ponieważ instytucje nie poddają się zmianom szokowym, o tyle w kryterium b) jak w soczewce ogniskują siẹ rezultaty zarówno zmian instytucjonalnych, jak i stabilizacyjnej polityki rządu. Kryterium b) jest zatem bardziej syntetyczne i dlatego może się okazać uźyteczne dla potrzeb analizy.

Znamienne jest, że bez względu na początkowo wybrany sposób dokonywania zmiany ekonomicznej, we wszystkich krajach postkomunistycznych pojawiała się transformacyjna recesja i depresja. Uznano ją (choć nie bez oporów) za trudny do uniknięcia koszt przechodzenia do gospodarki kapitalistycznej. Rzecz w tym, że obecnie kraje te dzielą się na dwie grupy. W pierwszej znajdują się kraje, w których od kilku lat istnieje wzrost gospodarczy o modernizującym się PKB; są to liderzy transformacji: Polska, Czechy, Węgry i Słowenia. Druga grupa natomiast obejmuje kraje pozbawione trwałego ożywienia gospodarczego (np. Ukraina, Rumunia) bądź kraje cechujące się co prawda wzrostem, lecz o tradycyjnej strukturze PKB (ten rodzaj produktu krajowego jest przeciwieństwem nowoczesnego, występując np. w Bułgarii). Ta grupa zatem składa się z outsiderów transformacji systemowej. 
Powstaje istotne pytanie o instytucjonalne cechy charakterystyczne dla grupy krajów, które odniosły sukces w postaci trwałego, aczkolwiek falującego wzrostu gospodarczego. Z punktu widzenia tych cech, grupa liderów transformacji jest stosunkowo jednorodna.

Po pierwsze, w przodujących krajach postkomunistycznych moźna obserwować stałą, trwającą od lat determinację w dziedzinie umacniania i doskonalenia demokracji parlamentarnej. Przykładem jest Polska, gdzie w 1997 r. uchwalono nową Konstytucję, później zaś wdrożono reformę administracji publicznej, obejmującą m.in. tworzenie słuźby cywilnej. Wszystko to sprzyja rozwojowi wolności ekonomicznej, co oznacza, że bez względu na polityczne zaplecze kolejnych rządów, w kraju stale są kreowane instytucje rynkowe znamienne dla ładu kapitalistycznego.

Po drugie, w grupie liderów transformacji dokonano znaczącej deregulacji, która zaowocowała zarówno wycofaniem siẹ rządu z kompleksowego ksztaltowania gospodarki, jak i zmianą jego ekonomicznej roli. Spowodowało to z jednej strony - wzrost znaczenia poziomej koordynacji decyzji przedsiębiorstw oraz informacji cenowej, z drugiej zaś koncentrację aktywności państwa wokół reguł podziału PKB. Inaczej jednak niż w przypadku przemian politycznych, w obszarze deregulacji wystąpiły wiẹksze różnice między krajami, zarówno co do tempa, jak i zakresu tego zjawiska.

Po trzecie, skomercjalizowano sektor przedsiębiorstw państwowych, poddając go rygorom gry rynkowej, równocześnie zlikwidowany został tzw. jednolity fundusz własności państwowej na rzecz firm w postaci jednoosobowych spółek skarbu państwa. Znacznie ważniejszy, bo oparty na decyzjach politycznych, okazał się program prywatyzacji kreujący w praktyce wiązkę praw własności: uźywania, korzystania i rozporządzania zasobami (przy czym „korzystanie" oznacza tu prawo właściciela do czerpania dochodów z tytułu uslug produkcyjnych, świadczonych przez zasoby). W rezultacie realizacji tego programu, udzial sektora prywatnego w tworzeniu PKB w grupie liderów transformacji wynosi od 60 do $70 \%$, przez co sektor ten wywiera konkurencyjną presję na sektor przedsiębiorstw publicznych (Kolodko, 1999). Najwyższym wskaźnikiem udziału (70\%) legitymują się Czechy, chociaż nie przekłada się on bezpośrednio na najwyższą w grupie efektywność procesów prywatyzacji (zwłaszcza „kuponowa” prywatyzacja budzi wiele zastrzeżeń).

Po czwarte, zliberalizowano gospodarkẹ przede wszystkim za pomocą uwolnienia cen rynkowych, wprowadzenia wewnętrznej wymienialności waluty krajowej oraz otwarcia gospodarki na świat (m.in. zniesienie barier importowych, koncesji eksportowych). Wszystkie te przedsięwzięcia sprzyjały wewnętrznej i zewnętrznej konkurencji zarówno na rynkach towarowych, jak i finansowych. Warto przy tym zauważyć, że liberalizacja cen miała podwójny wymiar: instytucjonalny, gdyż przekształcono ceny regulowane w ceny popytowo-podażowe, a także stabilizacyjny, ponieważ uwolnienie cen stało siẹ elementem pakietów makroekonomicznej stabilizacji. 
Po piąte, nie mniej ważną cechą grupy liderów transformacji okazały się silne tendencje integracyjne $\mathrm{w}$ dziedzinie międzynarodowej wymiany handlowej. Znalazły one wyraz - w mniejszym stopniu - w utworzeniu Trójkąta Wyszegradzkiego oraz - w większym stopniu - manifestowały się podpisaniem przez Węgry, Czechy i Polskẹ umów o stowarzyszeniu ze Wspólnotami Europejskimi (Kawecka-Wyrzykowska, 1997). Te i inne zabiegi integracyjne (np. czlonkostwo tych krajów w WTO) spowodowały zarówno implementację nowych instrumentów polityki handlowej, jak i zmianę struktury bilansu handlowego liderów transformacji na rzecz partnerów z Zachodu.

Sposób, w jaki wymienione kraje postkomunistyczne wkroczyły na drogę stabilizacji makroekonomicznej, nie był jednakowy. W niektórych krajach zastosowano tzw. terapię szokową, odnoszącą się glównie do sfery pieniądza i finansów publicznych. Terapia ta miała za zadanie wyeliminowanie niedoboru towarów, opanowanie wysokiej inflacji i zapewnienie wewnętrznej oraz zewnẹtrznej równowagi finansowej. U podstaw stabilizacyjnej polityki rządu legło przekonanie, iż działania równoważące budżet i liberalizacja cen nie bẹdą prowadziły do inflacji jedynie pod warunkiem „zakotwiczenia” całego układu finansowego, zaś rolę „kotwic” pełniły: twarda polityka budżetowa, restrykcyjna polityka monetarna banku centralnego, niemal całkowite zamrożenie płac oraz jednolity stały kurs walutowy. Tak rozumiana terapia szokowa, prowadząca do gwałtownego ograniczenia popytu globalnego w gospodarce, została konsekwentnie przeprowadzona w Polsce.

Były jednak kraje, które wybrały drogę gradualizmu, czyli wolniejszego stabilizowania sfery pieniądza i finansów publicznych (stopniowo też wprowadzano do gospodarki niektóre nowe instytucje, np. rynki finansowe). Uznano bowiem, że z jednej strony sytuacja wyjściowa nie wymagała tak drastycznego antidotum, z drugiej strony zaś wolniejsze przechodzenie do ustabilizowanej gospodarki rynkowej powinno było obniżyć spoleczne koszty w formie utraty cześci dochodu narodowego i poziomu życia gospodarstw domowych. W taki właśnie sposób rozpoczęto transformację systemową na Węgrzech.

Jeśli jednak spojrzeć na całą dekadę, to okaże się, że te dwie drogi do dojrzałego kapitalizmu niekiedy następowały po sobie. Na przykład w Polsce, po okresie stabilizacyjnego szoku w latach 1990-1993, nastąpiło osłabienie restrykcyjności polityki fiskalno-monetarnej, by od roku 1997 ustąpić miejsca ponownemu ograniczaniu popytu globalnego. Również na Węgrzech w 1995 r. dokonano istotnej zmiany: położono kres gradualizmowi, który - wbrew przewidywaniom i nadziejom - nie ustrzegł kraju przed transformacyjnym kryzysem. Otóż w ciągu czterech początkowych lat transformacji nastąpił blisko $20 \%$ spadek dochodu narodowego, zaś w polowie dekady zadłużenie zagraniczne brutto siẹgało powyżej 70\% PKB (Góralczyk, 2000). Dopiero radykalny stabilizacyjny pakiet Bokrosa, powiązany z instytucjonalną liberalizacją gospodarki, zatrzymał ten niekorzystny trend wprowadzając Węgry na świeźkę wzrostu. Ogólnie moźna zatem stwierdzić, że w poszczególnych krajach i w danym momencie, polityka stabilizacyjna zależała od makroekonomicznej sytu- 
acji oraz - co nie mniej ważne - od opcji politycznej, którą reprezentował rząd,

W dziedzinie efektów stabilizacyjnych, interesujących informacji dostarcza tablica 2. Zawiera ona dane, z których wynika, że w latach 1990-1991 wszystkie kraje zaliczone do grupy liderów, doświadczyły transformacyjnej recesji i depresji, i to bez względu na sposób stabilizowania gospodarki: szokowy lub stopniowy. Rzecz w tym, iż różne było tempo narastania recesji, a także tempo odzyskiwania realnego PKB, lecz już o innej, nowoczesnej strukturze rzeczowej. Tak więc Polska, w której konsekwentnie przeprowadzono szokową terapię, największy spadek realnego PKB odnotowała w pierwszym roku stabilizacji, natomiast już w 1992 r. pojawił się stały i stabilny przyrost PKB. W sumie dało to imponujący efekt końcowy, gdyż właśnie Polska okazała się „tygrysem” Europy Wschodniej: jeśli przyjąć rok 1989 za 100\%, to w $1998 \mathrm{r}$. łączny przyrost PKB oblicza się na $119 \%$; żaden z pozostałych liderów nie legitymuje się takim rezultatem.

Tabl. 2

Zmiany realnego PKB w krajach postkomunistycznych w latach 1990-1998 (w \%)

\begin{tabular}{|l|r|r|r|r|r|r|r|r|r|r|r|}
\hline & 1990 & 1991 & 1992 & 1993 & 1994 & 1995 & 1996 & 1997 & $1998^{*}$ & 1997 & 1998 \\
\cline { 2 - 11 } \multicolumn{1}{|c|}{ Kraj } & & & & & & & & & & \multicolumn{1}{c|}{$1989=100$} \\
\hline Bialoruś & $-3,0$ & $-1,2$ & $-9,6$ & $-7,6$ & $-12,6$ & $-10,4$ & 2,6 & 10,0 & $-7,1$ & 70,8 & 65,7 \\
Butgaria & $-9,1$ & $-11,7$ & $-7,3$ & $-1,5$ & 1,8 & 2,1 & $-10,9$ & $-7,4$ & 3,5 & 62,8 & 65,0 \\
Czechy & $-0,4$ & $-14,2$ & $-3,3$ & 0,6 & 3,2 & 6,4 & 3,9 & $-1,0$ & $-1,4$ & 95,8 & 97,1 \\
Estonia & $-8,1$ & $-7,9$ & $-14,2$ & $-8,5$ & $-1,8$ & 4,3 & 4,0 & 10,0 & 6,4 & 77,9 & 82,8 \\
Polska & $-11,6$ & $-7,0$ & 2,6 & 3,8 & 5,2 & 7,0 & 6,1 & 6,9 & 6,5 & 111,8 & 119,0 \\
Rosja & $-4,0$ & $-13,0$ & $-14,5$ & $-8,7$ & $-12,6$ & $-4,0$ & $-4,9$ & 0,4 & $-0,4$ & 52,2 & 52,0 \\
Rumunia & $-5,6$ & $-12,9$ & $-8,7$ & 1,5 & 3,9 & 7,1 & 4,1 & $-6,6$ & $-2,1$ & 82,4 & 80,7 \\
Slowacja & $-2,5$ & $-14,6$ & $-6,5$ & $-3,7$ & 4,9 & 6,8 & 6,9 & 6,5 & 4,0 & 95,6 & 99,5 \\
Slowenia & $-4,7$ & $-8,1$ & $-5,5$ & 2,8 & 5,3 & 4,1 & 3,1 & 3,3 & 4,1 & 99,3 & 103,4 \\
Ukraina & $-3,4$ & $-9,0$ & $-13,7$ & $-14,2$ & $-23,0$ & $-12,2$ & $-10,0$ & $-3,2$ & $-1,2$ & 38,3 & 38,8 \\
Węgry & $-3,5$ & $-11,9$ & $-3,1$ & $-0,6$ & 2,9 & 1,5 & 1,3 & 4,3 & 5,4 & 90,4 & 95,2 \\
\hline
\end{tabular}

Dane szacunkowe

Źródlo: Transition, 1998

Z kolei kraje, w których nie zastosowano terapii szokowej (Czechy, Wẹgry, Słowenia), największy recesyjny spadek PKB zanotowały w drugim bądź kolejnym roku stabilizacji, nieco wolniej też odzyskiwały realny produkt krajowy brutto. Ponadto łączny przyrost PKB, niemal w dekadzie, okazał się wy. raźnie mniejszy niż w przypadku Polski, gdyż jedynie Słowenia osiągnęła stopę wzrostu równą $103,4 \%$, natomiast w pozostałych krajach stopa ta ukształtowała się poniżej $100 \%$. 
Tabl. 3

Inflacja w krajach postkomunistycznych w latach 1991-1998 (na 31 XII, w \%)

\begin{tabular}{|l|r|r|r|r|r|r|r|r|}
\hline \multicolumn{1}{|c|}{ Kraj } & 1991 & 1992 & 1993 & 1994 & 1995 & 1996 & 1997 & $1998^{*}$ \\
\hline Bialoruś & 93,0 & 1159,0 & 1996,0 & 1960,0 & 244,0 & 39,2 & 63,1 & 84,0 \\
Butgaria & 339,0 & 79,4 & 63,8 & 121,9 & 32,8 & 310,8 & 578,6 & 17,0 \\
Czechy & 52,0 & 12,7 & 18,2 & 9,7 & 7,9 & 8,6 & 10,0 & 11,5 \\
Estonia & 304,0 & 953,5 & 35,6 & 42,0 & 29,0 & 15,0 & 12,0 & 11,0 \\
Polska & 60,0 & 44,3 & 37,6 & 29,4 & 21,6 & 18,5 & 13,2 & 10,0 \\
Rosja & 144,0 & 2508,8 & 840,1 & 204,7 & 131,3 & 21,8 & 11,1 & 10,0 \\
Rumunia & 223,0 & 199,2 & 295,5 & 61,7 & 27,8 & 56,9 & 151,6 & 47,0 \\
Slowacja & 58,0 & 9,1 & 25,1 & 11,7 & 7,2 & 5,4 & 6,4 & 7,0 \\
Slowenia & 247,0 & 92,9 & 22,9 & 18,3 & 8,6 & 8,8 & 9,4 & 8,0 \\
Ukraina & 161,0 & 2730,0 & 10155,0 & 401,0 & 182,0 & 39,7 & 10,1 & 19,0 \\
Wẹgry & 32,0 & 21,6 & 21,1 & 21,2 & 28,3 & 19,8 & 18,4 & 14,0 \\
\hline
\end{tabular}

Dane szacunkowe

Żródlo: Transition, 1998

Większe różnice wystąpily między omawianymi krajami w dziedzinie osiągania wewnętrznej równowagi finansowej (tablica 3). Ograniczając analizẹ do inflacji, naležy wskazać na odmienną sytuację wyjściową: w 1991 r. Słowenię trapiła inflacja na poziomie $247 \%$, podczas gdy np. na Węgrzech wyniosła ona zaledwie $32 \%$. Kolejne lata stabilizowania gospodarki w grupie liderów transformacji, przyniosły stopniowy i, w zasadzie, stały spadek inflacji, chociaż i pod tym względem sytuacja w 1998 r. okazała się zróźnicowana. Mianowicie, jednocyfrową inflację (liczoną na dzień 31 grudnia) udało się zapewnić jedynie w Słowenii, podczas gdy w pozostałych krajach wzrost przeciętnego poziomu cen konsumpcyjnych nie był niższy niż $10 \%$.

Dogłębna analiza determinant efektów stabilizacyjnych w postaci opanowania inflacji i zainicjowania wzrostu, jakie wystąpiły w grupie liderów, wykracza poza ramy artykułu. Warto jednak porównawczo zanalizować przypadki Polski i Wẹgier, gdyż (jak wspomniano) w 1995 r. gospodarka wẹgierska została poddana terapii szokowej zbliżonej do tej, która zainicjowała przemiany w gospodarce polskiej (wystạpiło tu zatem „przesuniẹcie w czasie”).

Ogólnie biorąc, istotą polityki makroekonomicznej stabilizacji jest ograniczenie nadmiernego popytu globalnego, głównie za pomocą restrykcyjnej polityki fiskalno-monetarnej (uzupełnionej przez instrumenty administracyjne). W rezultacie najpierw nastẹpuje załamanie się popytu, następnie zaś jego restrukturyzacja. W przypadku dostosowań ze strony podaży zagregowanej, należy odnotować nieuchronne odroczenie mające przyczynę o charakterze technicznym. Tak czy inaczej, stabilizacja i liberalizacja na ogół prowadzą do transformacyjnej recesji.

Jednak traktowanie pakietu stabilizacyjnego jako jedynego źródła spadku PKB byłoby nie uzasadnione, o czym świadczy właśnie przypadek Wẹgier: Otóż absoltune zmniejszenie się realnego PKB poprzedziło wdrożenie tego pa- 
kietu, świadcząc o błędach w polityce makroekonomicznej trzech kolejnych ministrów finansów (Góralczyk, 2000). Natomiast w latach 1995-1996 wystąpiło zaledwie spowolnienie wzrostu gospodarczego. W dziedzinie zjawisk inflacyjnych rok 1995 charakteryzował się wyraźną inflacją korekcyjną, ale począwszy od nastẹpnego roku stopa inflacji wykazywała tendencję malejącą.

W przypadku Polski stabilizacja i wzrost wyglądały zgoła inaczej. Tak więc głęboki, recesyjny spadek realnego PKB uwidocznił się w ciągu dwóch początkowych lat stabilizowania gospodarki. Należy przypuszczać, że był on nastẹpstwem zarówno złej struktury zdolności produkcyjnych, jak i bardzo restrykcyjnej polityki stabilizacyjnej. Wejście gospodarki na ścieżkę nowoczesnego wzrostu pojawilo się z kilkuletnim odroczeniem, w warunkach permanentnego obniżania się wskaźnika inflacji z rekordowego poziomu 249,3\% w $1990 \mathrm{r}$.

Dotychczasowa analiza prowadzi do istotnych wniosków: a) w Polsce zastosowano - prawdopodobnie - nadmiernie restrykcyjną politykę makroekonomiczną, o czym świadczy duży spadek produkcji finalnej, który przyniósł impuls inflacyjny; b) węgierski pakiet stabilizacyjny okazał się bardziej efektywny w tym znaczeniu, że spowodowal wprawdzie wolniejszy spadek inflacji, lecz równocześnie w ogóle nie wywolat recesji (nawiasem mówiąc, poziom inflacji w obu krajach wyrównał się w 1999 r.).

\section{„Drogi dojścia”: outsiderzy transformacji}

Grupa outsiderów transformacji systemowej jest wewnętrznie niejednorodna, co oznacza, że tworzące ją kraje więcej dzieli niż łączy. Najbardziej istotne różnice wydają się pozostawać w sferze instytucjonalnej, zaś ich wspólnym mianownikiem jest swego rodzaju „modelowa dewiacja”, rozumiana jako daleko idące odstępstwo od rynkowego układu docelowego. „Modelowa dewiacja" przybiera następujące formy instytucjonalne: a) socjalizmu rynkowo-reglamentacyjnego; b) kapitalizmu mafijno-oligarchicznego; c) kapitalizmu redystrybucyjnego (charakterystykę tych form zawiera tablica 4).

Pozornie, w socjalizmie rynkowo-reglamentacyjnym, którego jedynym obecnie przykładem jest Białoruś, władza polityczna jest z mocy prawa oddzielona od gospodarki. W rzeczywistości jednak decyzje polityczne (często podejmowane osobiście przez prezydenta) w szerokim zakresie oddziałują na redystrybucję dochodu narodowego, poziom cen czy kierunki wymiany handlowej z zagranicą (wyraźne ciążenie ku Rosji). W tym modelu dominuje grupowa lub państwowa własność zasobów: szacuje się, że udział sektora prywatnego w kreacji PKB wynosi zaledwie około 15\% (Kolodko, 1999: 117). Mechanizm rynkowy z jego poziomą koordynacją decyzji nie stanowi podstawowego instrumentu alokacji zasobów; przeciwnie, jest on podporządkowany decyzjom administracyjnym (w układzie pionowym), dotyczącym cen lub nawet reglamentacji zasobów i produktów (zwłaszcza konsumpcyjnych). Co więcej, mamy tu do czynienia z silnym ograniczeniem istnienia rynków finansowych, podporządkowaniem sektora bankowego kontroli politycznej czy kryzysem 
pieniądza w sieci rozliczeń (Europa, 1999). W omawianym modelu system instytucjonalny jest wewnętrznie sprzeczny, zaś jego dysfunkcje pojawiają się w sposób stochastyczny pod wpływem bieżących decyzji politycznych.

Tabl. 4

„Modelowa dewiacja” $\mathrm{w}$ procesie transformacji systemowej

\begin{tabular}{|c|c|}
\hline „Modelowa dewiacja" & Charakterystyka \\
\hline $\begin{array}{l}\text { Socjalizm } \\
\text { rynkowo-reglamentacyjny }\end{array}$ & $\begin{array}{l}\text { Decyzje polityczne w szerokim zakresie oddziałują na redystrybucję } \\
\text { dochodu narodowego, poziom cen lub wspólpracẹ z zagranica. } \\
\text { System instytucjonalny jest wewnętrznie sprzeczny, a przez to } \\
\text { dysfunkcjonalny. Trend wzrostu jest malejacy, zaś inflacja najwyższa } \\
\text { w grupie outsiderów ( } 84 \%) \text {. }\end{array}$ \\
\hline $\begin{array}{l}\text { Kapitalizm } \\
\text { mafijno-oligarchiczny }\end{array}$ & $\begin{array}{l}\text { Model ten jest, po częśi, oparty na rynkowym mechanizmie alokacji } \\
\text { i podziału. Odznacza się jednak związkami miẹdzy światem } \\
\text { przestẹpczym, biznesem a wladzą politycmą. Istnieje ekspansja } \\
\text { oligarchii finansowej kontrolującej instytucje państwa. Trend wrostu } \\
\text { jest silnie malejący, lecz inflacja pozostaje pod kontrolą (10\%). }\end{array}$ \\
\hline Kapitalizm redystrybucyjny & $\begin{array}{l}\text { Charakterystyczną cechą jest redystrybucja dochodu narodowego } \\
\text { w układzie gatęziowo-branżowym ilub regionalnym. Przyjmuje ona } \\
\text { formy: a) dotacji i subwencji budżetowych; b) szarej, nie opodatkowanej } \\
\text { strefy. Trend wzrostu jest raczej malejący bądź lekko rosnący, inflacja } \\
\text { zaś wysoka lub bardzo wysoka ( } 17 \% ; 47 \%) \text {. }\end{array}$ \\
\hline
\end{tabular}

Żródło: opracowanie wlasne

Model, który umownie można nazwać kapitalizmem mafijno-oligarchicznym, jest bardziej zbliżony do rozwiniętej gospodarki rynkowej, stanowiąc odwzorowanie gospodarki rosyjskiej. Inaczej niż w poprzednim modelu, silna władza prezydencka nie ingeruje w bieżące funkcjonowanie gospodarki za pomocą decyzji, które bezpośrednio lub pośrednio dotyczą np. poziomu cen, strumieni rzeczowych czy współpracy z zagranicą. Oznacza to, że mechanizm rynkowy w wyższym niż poprzednio stopniu alokuje zasoby, zaś formalny udział sektora prywatnego w kreacji PKB szacuje się na około 55\%. Równocześnie jednak model ten cechuje się dewiacją w postaci sprzecznych z prawem związków miẹdzy światem przestępczym, biznesem a władzą wykonawczą i parlamentem. Obserwuje się również rozwój systemu oligarchicznego w dziedzinie kapitału finansowego (Staniszkis, 1999). Chodzi o ekspansję i łączenie się tego kapitału z kapitałem przemysłowym, a także o kredytowanie przez oligarchię finansową państwa i sfery polityki; w zamian otrzymuje ona kontrolę eksportujących firm państwowych.

Model, który wprawdzie zmierza do rynkowego układu docelowego, lecz jest dotknięty dewiacją redystrybucyjną, odpowiada gospodarce w Bułgarii, Rumunii i Rosji (ta ostatnia stanowi jednak odrę̧ny przypadek, gdyż w Rosji redystrybucja jest jedynie nastẹpstwem innych cech instytucjonalnych). Wśród wielu wad charakterystycznych dla tego modelu, dominująca wydaje się ta, 
która polega na znaczącej redystrybucji dochodu narodowego. Podstawowym jej celem jest zmiana podziału wypracowanego produktu poprzez finanse publiczne, równocześnie jednak proces redystrybucji pozostaje - w pewnym zakresie - poza kontrolą państwa. W pierwszym przypadku chodzi o przesuwanie środków miẹdzy przedsiębiorstwami, branżami, gałęziami lub regionami za pomocą subwencji bądź dotacji celowych. Drugi przypadek natomiast dotyczy istnienia szarej strefy w gospodarce, która - nie placąc podatków - nieformalnie przechwytuje pewną część dochodu narodowego; w omawianym modelu udział tej strefy w kreacji PKB szacowany jest na więcej niż $20 \%$. Odrębnym (choć dającym ten sam skutek) zjawiskiem jest korupcja i związki mafijne splatające grupy biznesu ze światem polityki.

Uwzględniając dążenie outsiderów transformacji do stabilizacji i odbudowy PKB, należy wskazać na kilka kwestii. Po pierwsze, w początkowym okresie przemian stabilizacja makroekonomiczna przebiegała powoli i, co nie mniej ważne, niekonsekwentnie, powodując m.in. duże deficyty budżetowe i ogromną inflację (w tej ostatniej dziedzinie prym wiodły: Ukraina i Białoruś). Stałe pogarszanie się sytuacji makroekonomicznej zmusiło rząd w Rosji do dokonania radykalnej terapii w latach 1996-1997; podobne przedsiẹwzięcia stabilizacyjne zostały przeprowadzone w Bułgarii i Rumunii w 1997 r. Jednak efekty stabilizacyjne we wszystkich tych krajach są niezadowalające, przede wszystkim zaś odbiegają one od tych w grupie liderów transformacji.

Po drugie, pomijając na razie tempo odzyskiwania PKB, warto podkreślić, iż z punktu widzenia rzeczowej charakterystyki produktu tworzonego np. w Rosji, Białorusi czy Ukrainie, produkt ten prezentuje się niekorzystnie na tle PKB w grupie liderów, zwłaszcza pod względem jakości oraz nowoczesności struktury. Dalej, również tempo odzyskiwania PKB jest wolne, zaś absolutnym outsiderem jest tu Ukraina, a tuż za nią Rosja (stopy przyrostu realnego PKB wynoszą, odpowiednio, 38,8\% oraz 52,0\%). Ogólnie można stwierdzić, że w krajach dotkniętych "modelową dewiacją" powszechnie wystẹpuje malejący trend wzrostu gospodarczego (przynajmniej do 1998 r.).

\section{Podsumowanie}

Wprawdzie krytykowany przez Hayeka „konstruktywizm” jest mało obiecujący również w odniesieniu do procesu transformacji systemowej, to jednak jest niewątpliwe, że atrybuty współczesnej gospodarki rozwiniętej tworzą pewien układ docelowy dla krajów postkomunistycznych. Dążąc do jego osiągnięcia, kraje te przemierzają dystans rozwojowy dwiema różnymi drogami. Analiza dowiodła, że pierwsza $\mathrm{z}$ nich to droga stopniowego sukcesu, natomiast druga droga może być utożsamiana ze stopniową porażką.

Jednym z czynników, które różnicują drogi dojścia do układu docelowego, jest kultura polityczna, chyba nie doceniana przez analityków gospodarki. Historycznie rzecz ujmując, kraje zaliczone do liderów transformacji zawsze miały wiele wspólnego z kulturą polityczną Europy Zachodniej, w pewnych 
okresach po prostu ją współtworzyły (np. Austro-Wẹgry). Natomiast kraje pozostające obecnie w grupie outsiderów transformacji, miały najczęściej własną, odrębną kulturę polityczną, pozostającą w opozycji do demokracji parlamentarnej. Nie stanowiło to dobrej podstawy dla rozwoju wolności ekonomicznej.

Kolejny czynnik, który różnicuje drogi dojścia do rynku, również narastał historycznie: chodzi o wielkość tzw. inwestycji autonomicznych oraz konsumpcji autonomicznej. Te dwie wielkości ekonomiczne są charakterystyczne dla każdej gospodarki z osobna i nie zależą od bieżącej koniunktury gospodarczej, nigdy też nie obniżają się nawet podczas depresji. W przypadku krajów postkomunistycznych rola inwestycji i konsumpcji o charakterze autonomicznym polega nie tyle na stabilizowaniu koniunktury, ile na determinowaniu szans w dziedzinie pomyślnej transformacji. Im wyższy bowiem poziom bogactwa narodowego, zakumulowanego na przestrzeni stuleci, tym większe szanse na transformacyjny sukces. Czynnik ten sprawia, iż gospodarka narodowa w mniejszym stopniu odczuwa erozję, której źródłem jest transformacyjna recesja. Tę prawidłowość wydaje się potwierdzać przede wszystkim przypadek Czech, a po części i Wẹgier. Jest przy tym oczywiste, iż zaobserwowana prawidłowość działa również w przeciwnym kierunku, o czym świadczy przykład choćby Litwy, Białorusi czy Rumunii.

Pozostając konsekwentnie w obszarze czynników historycznych, warto wskazać na znaczenie wcześniejszych reform ekonomicznych, ukierunkowanych na implementację pewnych instytucji rynkowych, np. cen popytowo-podażowych, prywatyzacji handlu, usług, rzemiosła, pieniądza jako działającej kategorii ekonomicznej. Tego rodzaju reformy, ułatwiając później dokonanie przełomowej transformacji, wielokrotnie miały miejsce w grupie liderów. Co więcej, z wyprzedzeniem w stosunku do transformacji reformy te często wprowadzały kraje komunistyczne do miẹdzynarodowych organizacji finansowych, takich jak Bank Światowy lub MFW.

Nie bez znaczenia dla sukcesu lub porażki w procesie transformacji, okazała się konsekwencja i spoleczno-polityczna determinacja w dziedzinie stabilizowania gospodarki, mimo ewidentnych kosztów ogólnosystemowych terapii. W tych krajach, w których stabilizację podjęto zbyt późno lub połowicznie, zawrócenie z drogi utożsamianej ze stopniową porażką stało się niezwykle trudne.

To, co w grupie liderów stanowiło podstawę kreacji nowoczesnego PKB, czyli sprzężenie zwrotne między zmianami instytucjonalnymi a polityką stabilizacyjną, w ogóle nie wystąpiło lub pojawiło się w ograniczonej skali w grupie outsiderów.

Jednym z czynników obecnie i w przyszłości determinującym sukces transformacji, jest stałe dążenie kraju do włączenia się w proces globalizacji poprzez zinstytucjonalizowane struktury polityczne i gospodarcze. Kraje, które u progu kolejnego millennium wykazują tendencje autarkiczne (przykładem Białoruś), skazują się na marginalizację gospodarki bądź powrót do gospodarki niedoborów. Warto przy tym podkreślić, iż kraje pozbawione sukcesu trans- 
formacyjnego - niekiedy wbrew własnym intencjom - mogą być spychane przez Świat zewnętrzny w koleiny autarkii.

\section{Bibliografia}

Albert M. (1994): Kapitalizm kontra kapitalizm, Signum, Kraków.

Bossak J. (1990): Japonia. Strategia roziwoju w punkcie zwrotnym, PWN, Warszawa.

Buchanan J.M. (1997): Finanse publiczne w warunkach demokracji, PWN, Warszawa.

Domańska E. (1992): Wokól internvencji panistwa w gospodarke. Keynes, Friedman, Laffer, Kennedy, Reagan $i$ inni, PWN, Warszawa.

Dornbush R. (1996): Debt and Monetary Policy: The Policy Issues, The MIT Press, Cambridge, Massachusetts.

Europa (1999): Europa Środkowo-Wschodnia 1996. Rocznik VI, Instytut Studiów Politycznych PAN i Fundacja im. Friedricha Eberta, Warszawa.

Giddens A. (1999): The Third Way. The Renewal of Social Democracy, Cambridge UK.

Godłów-Legiẹdź J. (1992): Doktryna spoleczno-ekonomiczna Friedricha von Hayeka, PWN, Warszawa.

Grimm K. (1992): Socjalna gospodarka rynkowa w RFN, Fundacja im. Friedricha Eberta, Warszawa.

Góralczyk B. (2000): Dziesięć lat rynku, „Nowe Życie Gospodarcze” nr 21/261.

Havrylyshyn B. (1980): Road Maps to the Future. Towards More Effective Societies, Pergamon Press, Oxford - New York - Toronto.

Hussain Q., Wihlborg C. (1999): Corporate Insolvency Procedures and Bank Bahavior: A Study of Selected Asian Economies, IMF Working Paper WP/99/135.

Kawecka-Wyrzykowska E. (1997): Stostunki Polski ze Wspólnotami Europejskimi od 1989 roku. Szkola Glówna Handlowa. Warszawa.

Kolodko G.W. (1999): Od szoku do terapii. Ekonomia i polityka transformacji, Poltext, Warszawa.

Kowalik T. (2000): Wspólczesne systemy ekonomiczne. Powstawanie, ewolucja, kryzys, Wydawnictwo Wyższej Szkoły Przedsiębiorczości i Zarządzania im. Leona Kożmińskiego, Warszawa.

Koźmiński A.K. (1997): Jaki kapitalizm dla Polski? Wymiar ekonomiczny i spoleczny nowego porzadku, w: Ustrojowa wizja gospodarki polskiej, seria „Raporty” nr 55, IRiSS, Warszawa.

Murrell P. (1990): The Big Bang versus Evolution: East European Economic Reforms in the Light of Recent Economic History, „PlanEcon Report” nr 26.

Pejovich S. (1990): The Economics of Property Rights. Towards a Theory of Camparative Systems, Kluwer Academic Publishers, Dordrecht.

Staniszkis J. (1999): Instytucjonalna dynamika rosyjskiego kryzysu: implikacje dla Polski, „Gospodarka Narodowa" nr 1-2.

Thurow L.C. (1992): Head to Head, William Morrow and Co., Inc., New York.

Transition (1998): Transition Report Update, European Bank for Reconstruction and Development, London. 